\title{
Sectoral minimum wages in South Africa: disemployment by firm size and trade exposure \\ MARLIES PIEK \\ DIETER VON FINTEL
}

Stellenbosch Economic Working Papers: WP19/2018

www.ekon.sun.ac.za/wpapers/2018/wp192018

December 2018

KEYWORDS: Minimum wages, employment effects, firm size, international trade, concentration

JEL: F16, J43, J81, K31, L11

ReSEP (Research on Socio-Economic Policy)

http://resep.sun.ac.za

DEPARTMENT OF ECONOMICS

UNIVERSITY OF STELLENBOSCH

SOUTH AFRICA

A WORKING PAPER OF THE DEPARTMENT OF ECONOMICS AND THE BUREAU FOR ECONOMIC RESEARCH AT THE UNIVERSITY OF STELLENBOSCH

www.ekon.sun.ac.za/wpapers 


\title{
Sectoral minimum wages in South Africa: disemployment by firm size and trade exposure
}

\author{
Marlies Piek ${ }^{1} \&$ Dieter von Fintel ${ }^{1 ; 2}$
}

\begin{abstract}
$\underline{\text { Abstract }}$
This paper measures the impact of South African minimum wages on small and large firm employment in a sector that is exposed to international competition (agriculture) and one that is not (retail). Our results highlight that small firms in a tradable sector are the most vulnerable to minimum wage legislation. In particular, small farms shed jobs, while larger farms employed more unskilled workers as a result of minimum wages. Small firms were more affected by the minimum wage as they employed a higher proportion of low-skilled, low-wage workers. In contrast, large farms employed a lower proportion of low-skilled workers and used a more capital-intensive production process and were thus less affected by the legislation. While this shift represents a short-run response to minimum wages, it intensifies a long-run movement towards fewer, larger, more capital-intensive farms. Retail firms, on the other hand, do not exhibit the same behaviour, with zero employment losses in both small and large firms. This difference in result can be explained by the fact that firms that face international competition cannot easily increase prices when faced with wage increases. Non-tradable sectors, such as retail, can increase prices and shift the burden of higher labour costs onto the consumer as they do not face international competition. The effects of minimum wages in South Africa is, therefore, more complex than what previous research shows. We argue that an undifferentiated national minimum wage can result in intraindustry concentration and inequality could grow. This is true even if the economy-wide impact of a national minimum wage could be potentially benign.
\end{abstract}

\footnotetext{
${ }^{1}$ Department of Economics and Research on Socioeconomic Policy (ReSEP), Stellenbosch University; Private Bag X1, 7602, Matieland, South Africa. Email: marliesr@sun.ac.za

${ }^{2}$ Institute of Labor Economics (IZA), Bonn. Email: dieter2@sun.ac.za
} 


\section{$\underline{1 . \text { Introduction }}$}

In an attempt to reduce inequality (Leibbrandt et al., 2009) and decrease the number of working poor (Vermaak, 2012), the South African government is in the process of implementing a national minimum wage of R20 per hour. Other developing countries with similar socio-economic challenges (notably in the BRICS bloc, of which South Africa is also a member), have successfully followed this approach to reduce inequality (Lustig et al., 2013). While raising wages of the working poor can potentially reduce inequality, the threat of employment loss could enhance it. This paper focusses on employment changes, and is one of the first to consider the heterogeneous impacts of minimum wages within sectors in South Africa.

At this stage ${ }^{3}$, minimum wages in South Africa are still implemented selectively and with large differentiation, giving consideration to the specific circumstances of sectors, regions and firm sizes $^{4}$. While exemptions in some sectors and lower floors in others may minimize employment losses, the many details of sector-specific legislation introduce administrative burdens on employers. Bhorat et al. (2012) emphasise that low compliance in paying minimum wages may result from the complex minimum wage structure that has operated in South Africa ${ }^{5}$. A national minimum wage has the potential to partially remedy the problem of non-compliance. Developed countries, such as Germany, have also recently harmonized sector-specific minimum wages into one economy-wide wage-setting framework. This transition has reduced employment levels only marginally (Bossler \& Gerner, 2016).

South Africa's dual imperative of employment creation and inequality reduction introduces a policy tension: minimum wages potentially exert opposite pressures on both outcomes. A "blanket approach" - as embodied by a national minimum wage - could be beneficial for large-scale inequality reduction (including sectors that have not been covered by wage floors); a sector-

\footnotetext{
${ }^{3}$ At the time of writing, the national minimum wage was still in the process of being implemented.

4 Two independent mechanisms have determined minimum wages thus far. Sectoral determinations are legislated directly by central government, but only in selected sectors that employ the poorest workers in the labour market (such as agricultural, retail and domestic employees). Collective agreements, on the other hand, are agreed upon by industry bargaining councils - a collective of union representatives and firms who negotiate wages of better-paid workers (such as metal and clothing workers). These agreements can be extended to uncovered firms within the same sector and jurisdiction at the discretion of the Minister of Labour, regardless of whether employers and employees in these firms were party to the original agreement. These industry agreements, therefore, function in the same way as a conventional minimum wage. However, many workers are still not covered by either of these two mechanisms.
}

${ }^{5}$ Up to now, South Africa has had 124 different minimum wage structures (Cassim, Jourdan \& Pillay, 2015). 
specific approach could take into account vulnerabilities that can mitigate job losses in some segments of the economy. In this paper we evaluate the sector-specific approach, and focus on the experience of small firms - especially when these small firms operate in a sector that is exposed to international trade. Firms which produce tradable goods do not enjoy the same control over price mark-ups on their products, and therefore do not have the same options to recover higher labour costs from consumers as firms in non-tradable sectors do.

This paper analyses the effect of minimum wages (as imposed by sectoral determinations) by firm size in the agricultural and retail sectors. The agricultural sector, a tradable sector, is exposed to international competition. By contrast, the retail sector is closed to external markets. By comparing these two sectors, and considering heterogeneity by firm size, we assess whether the ability to absorb legislated wage increases is determined by economies of scale that are, in turn, associated with firm size; furthermore, we consider whether exposure to international markets is associated with greater employment losses resulting from limited power over price setting.

Our results show that most of the disemployment effects resulting from the introduction of minimum wages in the agricultural sector were concentrated amongst small farms. We show that minimum wages were more binding on small farms, since they hire a higher proportion of lowskilled, low-wage workers. Large farms use better-skilled workers and a more capital-intensive production process and thus the legislation did not decrease large farm employment. In stark contrast, large farms experienced employment growth. Small farms could not absorb the higher wage costs effectively, while large farms benefitted from the small farms' losses. This reflects a long-run trend whereby the number of commercial farmers has declined, but their scale has increased (Liebenberg \& Pardey, 2012). Minimum wages have, therefore, intensified an existing vulnerability. Coping with the simultaneous limitations of wage costs and selling produce in competitive international markets is therefore contingent on operating at scale. In contrast, the sensitivity of small firm employment is not apparent in the non-tradable retail sector that is relatively immune to international economic conditions. These results indicate that a more nuanced view is needed when evaluating the effects of minimum wages in South Africa.

Section two of this paper reviews international empirical evidence on the relationship between minimum wages and employment outcomes and discusses heterogeneous impacts of minimum wages on different sectors (tradable and non-tradable) and within sectors (between small and large 
firms). Section three introduces the dataset and key variables and discusses the estimation strategy and descriptive statistics. Thereafter, econometric results are presented. In the last section, we conclude and discuss policy implications.

\section{Literature review}

The impact of minimum wages on employment is perhaps one of the most studied and controversial topics in economics. Models of a perfectly competitive labour market predict that the introduction of minimum wages decrease employment (if the minimum wage is binding). However, if a monopsonistic labour market is assumed to hold, the effect of a minimum wage could either increase or decrease employment. It is therefore unclear whether minimum wages affect employment in the same manner across sectors and firm size. The international and South African empirical evidence highlights these potential differences, and is discussed below.

\section{$\underline{2.1 \text { Evidence of the impact of minimum wages }}$}

Research on the effect of minimum wages on employment outcomes is vast and spans over many decades. Brown et al. (1982) reviewed the first wave of the minimum wage literature and found that teenage employment elasticities (the percentage change in employment for a 1 per cent increase in wages) ranged between -0.1 and -0.3 . Until the early 1990s, the consensus was that a robust negative relationship between minimum wages and employment existed. This position was challenged by the results of Card (1992a, 1992b), Katz and Krueger (1992), and Machin and Manning (1994) (inter alia), which signaled the emergence of the new minimum wage literature and required updated theoretical perspectives. Card and Krueger's (1994) seminal study analysed the increase in minimum wages in New Jersey, and found - contrary to expectations - a very large positive effect on employment levels. However, in 2000 Neumark and Wascher reassessed these findings using payroll data and found elasticities ranging between -0.10 and -0.25 . In response to Neumark and Wascher's (2000) findings, Card and Krueger (2000) used data from the US Bureau of Labour Statistics to re-estimate the effect of minimum wages on employment in New Jersey's fast food restaurants and found a small but insignificant effect on employment. Perhaps an explanation for the three papers' diverging results (while studying the same geographical areas and types of restaurants), could be the use of different datasets and measurement error. 
Due to a lack of consensus about the relationship between minimum wages and low-wage employment, Neumark and Wascher (2007) conducted a meta-analysis of more than 100 studies. The majority found disemployment effects. In contrast, two recent revisionist studies by Allegretto et al. (2011) and Dube et al. (2010) found no disemployment effects as a result of minimum wage increases in the United States. However, Neumark et al. (2014) again reviewed these two studies and instead found significant elasticities of -0.1 and -0.2 .

Recently, Sorkin (2015) found that demand for labour is inelastic in the short run, but is elastic in the longer-term as employers can substitute away from labour towards capital. In line with this finding, Meer and West (2015) demonstrated the impact of minimum wages on employment and changes in employment growth over time. The authors discovered that minimum wages decrease employment growth and employment levels over a longer time period, instead of instantaneously.

The minimum wage literature in developing countries is scarcer and more recent. Fajmzylberg (2001) studied employment elasticities for Brazil and estimated them to be in the range of -0.05 and -0.08. Bell (1997), Maloney and Mendez (2004) and Arango and Pachon (2007) analysed elasticities for Colombia and found them to be between -0.02 and -0.12 . Gindling and Terrell $(2005,2007)$ looked at an increase in the minimum wage in Costa Rica and found that affected employers responded both at the extensive and intensive margin, by reducing employment by $1.09 \%$ and hours worked by $0.6 \%$ respectively.

Sectoral minimum wages were first introduced in South Africa in 1999, so that the evidence remains limited. In a pre-emptive simulation paper, Bhorat (2000) investigated the potential employment effects of the introduction of minimum wages for domestic and farm workers. The paper showed that employment would decrease as a result of the introduction of minimum wages. Studies by Conradie (2004) and Hertz (2005), which were conducted after implementation, confirmed the simulation results, both indicating that employment decreased for agricultural and domestic workers in response to the introduction of minimum wages in 2003. Conradie (2004) analysed the response of 190 grape farmers and estimated an employment decrease between $3 \%$ and $6 \%$ as the minimum wage increased by $10 \%$. Hertz (2005) found that, while total earnings increased for domestic workers, the estimated employment elasticity for domestic workers was -0.46 . 
In contrast, a case study of 103 farm workers in the sugar industry by Murray and van Walbeek (2007) found no large reduction in employment. Instead, employers reduced the number of hours worked to afford the higher labour costs.

Dinkelman and Ranchhod (2012) used a difference-in-difference model to analyse how employment and hours worked changed for domestic workers between 2001 and 2004, and found no reduction in the number of workers nor in hours worked. Bhorat et al. (2013) were the first to analyse employment outcomes in the retail, taxi, forestry and private security sectors, using a similar approach to that of Dinkelman and Ranchhod. While the authors found no significant impact of the laws at the extensive margin for any of the sectors, their results suggest that the retail, security and taxi sectors decreased working hours to afford the higher wage costs. Furthermore, Bhorat et al. (2013) found that real wages increased in four out of the five sectors analysed. Bhorat et al. (2014) studied the effect of the agricultural minimum wage on employment, wages and hours worked between 2000 and 2007. Their results indicate that employment decreased, while wages and hours worked increased in response to the introduction of minimum wages. Garbers (2014) analysed the effect of the agricultural minimum wage on employment from 1997 to 2007, using a fixed effects approach, and estimated employment elasticities for unskilled workers of -1.5.

In sum, where minimum wages did have disemployment effects in South Africa, the elasticities are large compared to other developing countries. Yet, in many sectors the effects are zero. Minimum wages therefore have heterogeneous, sector-specific impacts. This paper is one of the first to analyse the circumstances in which these differences arise. Two types of heterogeneity are discussed below: heterogeneity between tradable and non-tradable sectors, and heterogeneity within a sector, between small and large firms.

\subsection{Differences in the impact of minimum wages in tradable and non-tradable sectors}

A potential reason for cross-sectoral differences in measured impacts is that retail, private security and the taxi sectors are non-tradable and face no international competition. On the contrary, agriculture and the clothing industry produce goods that are tradable and thus face international competition. Since firms in non-tradable sectors face no international competition, they can raise prices and shift the burden of higher labour costs onto consumers. Consequently, there is no need to shed employment. To the contrary, firms in tradable sectors face international competition, and can therefore not shift the burden of higher labour costs onto the consumer. Therefore, when 
minimum wages are introduced in tradable sectors, firms decrease employment or shut down, as they cannot pay the higher wage costs.

Findings by Fedderke et al. (2006) support this reasoning. They found that import and, to a lesser extent, export penetration among South African manufacturers lead to lower price mark-ups. This emphasizes that tradable sectors which face international competition cannot increase prices in response to higher wage costs. Moreover, research by Rankin (2016) shows that small firms in the manufacturing sector, a tradable sector, are especially vulnerable to institutional wage setting. He notes that when labour-intensive small firms, which employ more low-skilled workers, are confronted with wage pressures from collective bargaining, higher levels of import competition exacerbate employment loss; many small firms exit the market in response.

This sub-section has shown that in the presence of wage increases, the response of firms is very different, depending on whether they are in a tradable or non-tradable sector. In addition, research by Rankin (2016) has pointed out that small firms in a tradable sector are particularly vulnerable. The next sub-section discusses how small and large firms are affected differently by minimum wages.

\section{$\underline{2.3 \text { Differences in the impact of minimum wages on small and large firms }}$}

Rama (2001) argues that for large firms, the monopsonistic model of minimum wages is more accurate whereas the competitive model is more applicable to small and medium sized firms. Firms of different sizes therefore respond inherently differently to the introduction of minimum wages. Research from Indonesia shows that employment effects differed by firm size (Del Carpio et al., 2012; Rama, 2001). Small firms experienced significant employment losses (as predicted by the competitive model), whereas large firms experienced an increase in employment (possible only with the monopsonistic model). This suggests that in certain circumstances small firms can be losers, whereas large firms can be winners from minimum wages.

Parrott (2004) used state-level differences in minimum wages in the United States to compare the impact of minimum wages on small firms to those of large firms. He concluded that small firms were not particularly negatively affected by minimum wages. Sabia (2006), however, pointed out that Parrott (2004) neither tested for statistical significance, nor did he control for confounding factors - such as socioeconomic and demographic factors. Sabia used econometric techniques and 
estimated that a $10 \%$ increase in the minimum wage, decreases employment in small firms by 0.8 1.2\%. The author found an even larger disemployment effect when looking at low skilled workers in small firms, where employment elasticities ranged between -0.48 and -0.88 .

Although the South African literature on the impact of sectoral minimum wages on small firms is somewhat silent, Magruder (2012) analysed the impact of bargaining councils that extend their collective agreements to small firms. Magruder found that bargaining councils reduced small firm employment by $7-16 \%$ while there was no effect on large firms. ${ }^{6}$

This evidence presented by Magruder (2012) points towards a feature of South African market structure: high levels of concentration exist, large firms dominate the market and are more immune to policy changes than small firms. Kerr et al. (2014) found that net job creation in South Africa occurred mainly within larger firms; small firms have limited capacity to grow employment. In addition, Matthee et al. (2015) showed that South African exports are dominated by a group of larger 'super-exporters'. Furthermore, Edwards et al. (2017) show that only the most productive firms are able to export. The overlap between these three empirical observations suggest that large firms are able to use the most productive inputs (capital and better-skilled workers), contributing to their profitability and allowing them to remain competitive in international markets; as a result of their scale, they are able to create new jobs which small firms cannot. By inference, these firms should also be able to weather minimum wage shocks. Small, labour-intensive firms in tradable sectors, on the other hand, do not hire the most productive workers and are therefore less likely to profitably maintain their employment levels in the face of higher labour costs.

The evidence presented above has shown that tradable sectors are more vulnerable to minimum wages, which often result in job losses or an exit of firms. However, mainly small firms within these sectors face these constraints. Non-tradable sectors do not face the same difficulties in employing workers in the context of wage increases. We formally highlight these differences by studying small and large firms in a sector open to international trade, compared to a sector that is not.

\footnotetext{
${ }^{6}$ Small firms are defined by the author as fewer than 10 employees and large firms defined as more than 20 employees.
} 


\section{$\underline{\text { 3. Data and estimation strategy }}$}

\subsection{The data}

We re-analyse data used by Bhorat et al. (2013, 2014), looking at the same sectors. However, we explore heterogeneity in the impacts of minimum wages. Data is comprised of 15 waves of the South African Labour Force Survey (LFS), from September 2000 to September 2007. The LFS is nationally representative and surveyed approximately 30000 households in each installment. Surveys were conducted in March and September of each year by Statistics South Africa. The waves were pooled and treated as repeated cross sections over time. The sample was restricted to the working age population, while self-employed individuals as well as union and government workers were excluded from the sample ${ }^{7}$.

Sectoral determinations are set by the Minister of Labour and are published in Government Gazettes $^{8}$. These sectoral determinations are set for specific groups of individuals and stipulate conditions of work, including minimum wages. The South African Standard Classification of Occupations (SASCO) and the International Standard Industrial Classification (ISIC) are reported in the LFS, and were used to identify minimum wage workers.

When the agricultural minimum wage was introduced in March 2003, it varied by geographical locations articulated as areas A and B. These demarcations were defined at a local municipality level, where area A represented more affluent local municipalities (and as a result had higher legislated minimum wages), while area B comprised of poorer and often more rural local municipalities (and thus had lower legislated minimum wages).

Complex minimum wage structures were introduced on 1 February 2003 in the retail sector, which varied by region, occupation and whether workers worked part- or full-time. In addition, firms with fewer than five employees were required to pay a lower minimum wage than firms with five or more employees, acknowledging the difficulties that small firms face in complying with wagesetting legislation. This concession was, however, removed in 2006.

\footnotetext{
${ }^{7}$ Union and government workers were excluded from the sample since their wages are often subject to collective bargaining agreements and including them would have confounded the two types of wage legislation.

${ }^{8}$ These are available on the Department of Labour's website, www.labour.gov.za.
} 


\section{$\underline{3.2 \text { Sample selection and key variables }}$}

The construction of treatment and control groups was guided by the analysis of Bhorat et al. (2013; 2014). The entire dataset was restricted to low-wage individuals ${ }^{9}$ in the working age population, who had less than 12 years of education ${ }^{10}$. Individuals who indicated that they worked more than 15 hours a day, as well as those who reported zero wages or had missing wages were not included in the sample.

Unique control groups for both the agricultural and retail sectors were created to assess if minimum wage impacts were unique to workers in these sectors. Control groups for the respective sectors were chosen based on having similar characteristics to the respective treatment groups. The control group used in the employment analysis for the agricultural sector consists of African and mixed race $^{11}$ individuals who were either employed or narrowly unemployed. For employed individuals, only those in elementary occupations are included. The retail sector's control group for the employment analysis comprised of employed and narrowly unemployed individuals ${ }^{12}$. Using broader control groups acknowledges that workers who have lost their jobs in the minimum wage sector could potentially find employment in the control sector, or become unemployed. The impact may therefore be mitigated by these kinds of movements. These control groups, therefore, include workers employed in other sectors and workers who were potentially affected by other minimum wages.

\section{$\underline{3.3 \text { Estimation strategy }}$}

The estimation strategy is based on Card and Krueger (1995) and Lee (1999). The difference-indifference model tests whether employment, hours worked and wages changed more in areas where wages were lower in the pre-law period - in other words, where the treatment intensity is higher and wages would have to be increased more to comply with minimum wage legislation.

\footnotetext{
${ }^{9}$ Defined as earning below R10 000 per month in 2000 Rands.

${ }^{10}$ This was done as minimum wages usually affect the low-wage and low-skilled workers the most and not the relatively more educated and better paid in each sector.

${ }^{11}$ Since the majority of farmworkers are African and of mixed race, the control group was restricted to these race groups to make the control group as similar to the treatment group as possible. It is furthermore known that different wage-determination processes operate for various race groups (Burger et al., 2016).

12 The employed people in this control group were not restricted by specific skill-levels, since the retail treatment group also included occupations over a range of different occupations and skill-levels.
} 


$$
Y_{i j k t}=\alpha_{0}+\alpha_{1} \text { Post }_{t}+\alpha_{2} \text { Wage gap }_{j k}+\alpha_{3} \text { Post }_{t} * \text { Wage gap }_{j k}+X_{i j k t}+\gamma_{i j k t}
$$

$Y_{i j k t}$ is the outcome of interest (employment, hours worked and wages) for individual $i$ in sector $k$, district council $j$ and period $t$. The Post $t_{t}$ variable is a dummy indicating periods after the introduction of minimum wages. The Wage gapjk variable measures the intensity of the introduction of minimum wages across the district councils ${ }^{13}$, based on initial wages in the period prior to the introduction of the law. The variable then, distinguishes between regions where wages had to rise the most to reach full compliance (and by implication would have the largest adjustments to local labour market outcomes - if indeed they took place), and is discussed in more detail below. $X_{i j k t}$ controls for individual characteristics such as age, education and race as well as real GDP, seasonality and district council variation. $\gamma_{i j k t}$ represents the error term.

The Wage gap $_{j k}$ variable is constructed as follows:

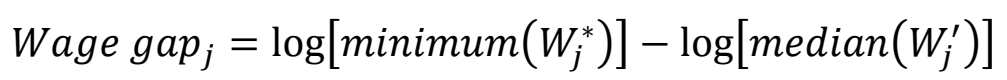

$W_{j}^{*}$ is the initial minimum wage in district $_{j}$ and $W_{j}^{\prime}$ is the median wage of the treated sector in district $_{j}$, in the year before minimum wages were implemented $(2002)^{14}$. The wage gap variable is zero for district councils where the median wage was already higher than the minimum wage at the time of implementation. To construct the wage gap variable, each individual in the dataset had to be assigned the hourly real minimum wage for the district council they reside in ${ }^{15}$. However, minimum wage regions (areas A and B) are defined by smaller municipal demarcations which cannot be identified in the data. District councils are the smallest demarcation that can be consistently identified throughout the period of analysis. A district council could therefore comprise of only area A municipalities, only area B municipalities or a mixture of area A and area B municipalities. Assigning minimum wages to individuals living in district councils comprising only of areas A or B is uncomplicated. For district councils that contain both areas, assigning a minimum wage is more complex. Population estimates from the 2007 Community Survey were used to calculate the percentage of the district councils' populations that lived in local

\footnotetext{
${ }^{13}$ South Africa is divided into 55 district councils. Minimum wages do not vary greatly by geography, except where these districts contain greater numbers of workers in either area A or B municipalities (which are smaller geographic units than district councils).

${ }^{14}$ Both the median and minimum wages are real hourly wages in 2000 Rands.

${ }^{15}$ All minimum wages were adjusted for inflation and converted into 2000 Rands, using CPI data from StatsSA.
} 
municipalities classified as A or B. These percentages were then assigned to each individual in the dataset depending on the district council in which the individual resided. Minimum wages for mixed district councils were then calculated as follows:

$\begin{aligned} E\left(\text { Minimum } \text { wage }_{j}=\right. & \% \text { of people living in area } A * \text { area } A \text { minimum wage } \\ & +\% \text { of people living in area } B * \text { area } B \text { minimum wage. }{ }^{16}\end{aligned}$

Each individual is assigned this weighted minimum wage according to their district of residence. This was then used to construct the wage gap variable, so that the impact of minimum wages on employment outcomes could be analysed. A similar method was followed for the retail sector, the main difference being that the retail minimum wage varied across three areas instead of two.

The coefficient on the interaction term $\left(\alpha_{3}\right)$ measures the change in outcomes attributable to the minimum wage in the post-law period. The model is run on the treatment and control groups for the employment analysis but is restricted to only the treated in the hours worked and wage analysis. The model is run with and without individual controls, dummies for seasonality and district councils.

\subsection{Descriptive statistics}

Table 1 shows the average wage gap for the agricultural and retail sectors across different firm sizes $^{17}$. The wage gap variable measures the intensity of the minimum wage legislation, based on median wages of workers in the year prior to the introduction of minimum wages. The higher the wage gap, the more wages had to increase to comply with the minimum wage legislation. The average wage gap in the agricultural sector was 0.47 . In other words, minimum wages were set at a level that is nearly $50 \%$ higher than the pre-policy median agricultural wage in each district. Notably, wage gaps only start to narrow noticeably for farms that employ 50 workers and more; large farms already had the greatest capacity to pay minimum wages before they were imposed. Turning to the retail sector, the wage gap of 0.23 is substantially lower than in the agricultural sector, indicating that the minimum wage was more binding in the agricultural sector than in the retail sector. Moreover, the wage gap is substantially higher for the firms with fewer than 5

\footnotetext{
${ }^{16}$ To clarify, each mixed district council would have a different minimum wage, depending on how many people in that district council lived in local municipalities classified as A or B.

${ }^{17}$ As mentioned earlier, retail minimum wages for firms with fewer than 5 employees were lower than those with 5 or more employees. We have therefore included these two firm size categories as well.
} 
employees than for firms with 5 employees or more. This was despite the fact that a higher minimum wage was imposed for the latter group. In addition, the minimum wages seemed to be more binding for firms with 5-19 employees compared to larger firms.

Table 2 shows the average characteristics for the agricultural and retail sectors, as well as its unique control groups over the entire sample period. Looking at the top panel of table 2, one sees that, on average, agricultural workers were more likely to be comprised of Africans, the middle aged, males and workers with very low levels of education (roughly five years of schooling). Real hourly wages in the agricultural sector decreased slightly between 2000 and 2002, after which they increased continually until 2007. This indicates that minimum wages did indeed raise farmworker wages. The number of hours worked by farmworkers decreased from 2000-2007, with a substantial decrease from 2002 to 2003, when the minimum wage was introduced. This suggests that employers may have adjusted on the intensive margin to be able to afford the higher labour costs.

On average, workers in the retail sector ${ }^{18}$ had around 10 years of schooling, and were also middleaged African individuals. Real wages in the retail sector increased from 2002 to 2007, which could imply that there was at least partial compliance with minimum wage legislation in the retail sector. In response to the higher wages, it does not seem that employers reduced the number of hours worked, with small fluctuations around 49 hours a week.

Table 1: Average wage gaps for the agricultural and retail sectors

\begin{tabular}{llll}
\hline Agricultural sector & & Retail sector & \\
\hline Entire sector & 0.47 & Entire sector & 0.23 \\
$<20$ employees & 0.50 & $<5$ employees & 0.33 \\
$\geq 20$ employees & 0.51 & $\geq 5$ employees & 0.22 \\
$<50$ employees & 0.45 & $5-19$ employees & 0.26 \\
$\geq 50$ employees & 0.40 & $\geq 20$ employees & 0.21 \\
& & 5-49 employees & 0.23 \\
& & $\geq 50$ employees & 0.23 \\
\hline
\end{tabular}

Source: Own calculations from South African Labour Force Survey from 2000 to 2007.

\footnotetext{
18 As mentioned previously, the retail minimum wage ranges across certain occupations, one of which include managers. Since managers are often relatively more educated and remunerated, another treatment group was created to see whether mean characteristics of the treatment group changed. Regressions with this treatment group were also run, but as with the mean characteristics, there were no substantial differences. For future research, one could perhaps split the retail minimum wage into a relatively more skilled and relatively less skilled groups, to get better control groups.
} 
Table 2: Average characteristics of the agricultural and retail sectors and their control groups

Agricultural sector

\begin{tabular}{lccc|ccccc}
\hline Year & $\mathbf{2 0 0 0}$ & $\mathbf{2 0 0 1}$ & $\mathbf{2 0 0 2}$ & $\mathbf{2 0 0 3}$ & $\mathbf{2 0 0 4}$ & $\mathbf{2 0 0 5}$ & $\mathbf{2 0 0 6}$ & $\mathbf{2 0 0 7}$ \\
\hline $\mathrm{N}$ & 1283 & 2857 & 3096 & 2810 & 3021 & 3011 & 3121 & 3045 \\
Education & $4.92^{*}$ & $4.88^{*}$ & $4.98^{*}$ & $5.15^{*}$ & $5.21^{*}$ & $5.55^{*}$ & $5.58^{*}$ & $5.77^{*}$ \\
Age & 35.22 & $35.74^{*}$ & 34.97 & $35.10^{*}$ & 35.26 & $35.04^{*}$ & $35.06^{*}$ & $35.35^{*}$ \\
Proportion African & $0.61^{*}$ & $0.66^{*}$ & $0.66^{*}$ & $0.63^{*}$ & $0.67^{*}$ & $0.69^{*}$ & $0.68^{*}$ & $0.70^{*}$ \\
Proportion male & $0.65^{*}$ & $0.67^{*}$ & $0.65^{*}$ & $0.66^{*}$ & $0.66^{*}$ & $0.67^{*}$ & $0.63^{*}$ & $0.66^{*}$ \\
Hours per week & $52^{*}$ & $51^{*}$ & $52^{*}$ & $50^{*}$ & $49^{*}$ & $50^{*}$ & $49^{*}$ & $49^{*}$ \\
Real hourly wage & $2.56^{*}$ & $2.56^{*}$ & $2.35^{*}$ & $2.68^{*}$ & $3.05^{*}$ & $3.34^{*}$ & $3.49^{*}$ & $3.62^{*}$
\end{tabular}

Control group for the agricultural sector

\begin{tabular}{lccc|ccccc}
\hline $\mathrm{N}$ & 1143 & 2227 & 2280 & 2280 & 2452 & 2323 & 2687 & 2860 \\
Education & 7.91 & 8.16 & 8.29 & 8.37 & 8.31 & 8.45 & 8.6 & 8.63 \\
Age & 34.48 & 33.99 & 34.8 & 34.39 & 34.69 & 34.02 & 34.167 & 34.07 \\
Proportion African & 0.76 & 0.75 & 0.75 & 0.78 & 0.79 & 0.79 & 0.77 & 0.81 \\
Proportion male & 0.68 & 0.69 & 0.68 & 0.67 & 0.7 & 0.71 & 0.69 & 0.7 \\
Hours per week & 48 & 47 & 47 & 46 & 47 & 47 & 46 & 46 \\
Real hourly wage & 6.64 & 6.6 & 6.49 & 6.12 & 6.21 & 6.27 & 6.7 & 6.6
\end{tabular}

Retail Sector

\begin{tabular}{lccc|ccccc}
\hline $\mathrm{N}$ & 853 & 1460 & 1387 & 1388 & 1362 & 1514 & 1690 & 1622 \\
Education & $9.66^{*}$ & $9.77^{*}$ & $9.83^{*}$ & $10.03^{*}$ & $10.24^{*}$ & $10.02^{*}$ & $10.23^{*}$ & $10.04^{*}$ \\
Age & $33.51^{*}$ & $33.45^{*}$ & $33.1^{*}$ & $33.63^{*}$ & $33.28^{*}$ & $33.83^{*}$ & $32.76^{*}$ & $33.54^{*}$ \\
Proportion African & $0.63^{*}$ & $0.64^{*}$ & $0.65^{*}$ & $0.63^{*}$ & $0.65^{*}$ & $0.63^{*}$ & $0.62^{*}$ & $0.65^{*}$ \\
Proportion male & $0.52^{*}$ & $0.47^{*}$ & $0.47^{*}$ & $0.49^{*}$ & $0.47^{*}$ & $0.48^{*}$ & $0.48^{*}$ & $0.49^{*}$ \\
Hours per week & $49^{*}$ & $49^{*}$ & $50^{*}$ & $49^{*}$ & $49^{*}$ & $50^{*}$ & $48^{*}$ & $48^{*}$ \\
Real hourly wage & 7.88 & $7.33^{*}$ & $6.57^{*}$ & 7.32 & 6.73 & 6.96 & 7.1 & 7.39
\end{tabular}

Control group for the retail sector

\begin{tabular}{lccc|ccccc}
\hline $\mathrm{N}$ & 2508 & 4345 & 3890 & 3604 & 3813 & 4346 & 4472 & 4535 \\
Education & 8.15 & 8.23 & 8.46 & 8.57 & 8.42 & 8.46 & 8.61 & 8.81 \\
Age & 36.01 & 35.56 & 36.03 & 35.67 & 35.64 & 35.16 & 35.17 & 34.96 \\
Proportion African & 0.72 & 0.72 & 0.71 & 0.72 & 0.73 & 0.73 & 0.72 & 0.73 \\
Proportion male & 0.68 & 0.66 & 0.66 & 0.66 & 0.68 & 0.69 & 0.68 & 0.67 \\
Hours per week & 47 & 47 & 47 & 46 & 46 & 47 & 46 & 46 \\
Real hourly wage & 8.09 & 7.92 & 7.34 & 7.07 & 6.99 & 7.03 & 7.38 & 7.47 \\
\hline
\end{tabular}

Notes: Own calculations using the South African Labour Force Survey from September 2000 to 2007. Given that the paper only used the September round of 2000, the sample sizes for the year 2000 are substantially smaller than the subsequent years which used the March and September rounds.

The dashed line indicates the timing of the law. ${ }^{*} \mathrm{p}<0.05$, indicating significant differences across treatment and control groups. 


\section{$\underline{\text { 4. Econometric results }}$}

\section{$\underline{4.1 \text { Results for the agricultural sector }}$}

We now turn to difference-in-difference results, starting with the agricultural sector. The analysis was split by farm employment size to uncover heterogeneity by firm size ${ }^{19}$. In particular, the analysis for the agricultural sector was split into four categories: farms with i) fewer than 20 employees, ii) fewer than 50 employees iii) 20 or more employees and iv) 50 or more employees. This section will first analyse the effect of minimum wages on employment, then the number of hours worked and lastly the wage results for the agricultural sector.

Table 3 shows the results from the impact of the introduction of minimum wages on employment in agriculture. Two sets of results are shown per table. The first set of results (in the top panel) does not include controls, whereas the second set of results (in the bottom panel) controls for race, education, gender and age as well as district council fixed effects, time dummies and agricultural real GDP. Each set of results is comprised of five regressions of which the first regression has no farm size restriction, followed by regressions in successive columns that restrict the sample to smaller and larger farms respectively. The dependent variable in table 3 is a binary variable and indicates if the individual is employed as a farmworker or falls within the control group as defined above. The sample therefore includes agricultural workers affected by the minimum wage, individuals who are looking for work or who are employed in elementary occupations in nonagricultural sectors, who could be affected by another minimum wage.

Column 1 of table 3 shows that the effect of the minimum wage is statistically insignificant. However, once one controls for district council fixed effects, seasonality, agricultural real GDP and other individual covariates in the first column of the second panel of results, the coefficient is negative and statistically significant. Employment decreased by about $1.1 \%$ in response to minimum wages. These results are similar to those found by Bhorat et al. (2014). Similar results apply to workers on farms with fewer than 20 and fewer than 50 employees. The difference-indifference coefficients are larger in columns 2 and 3 in both sets of results than for the unrestricted sample, indicating that most job losses occurred on smaller farms. In particular, the results indicate

\footnotetext{
${ }^{19}$ The measure used for firm size is self-reported by the individual and not by the firm. This measure could therefore underreport the number of workers in a firm, particularly if the firm has more than one division or plant.
} 
that in response to a one percent change in the initial wage gap, the probability of being a farmworker on a small farm decreased between $4.2 \%$ and $8.3 \%$ in the post-law period compared to the period before minimum wages were implemented. In contrast, the probability of employment on the very largest farms - those that employ more than 50 workers - increased by roughly $4 \%$ in response to the minimum wage.

Table 3: Probability of employment in the agricultural sector

\begin{tabular}{|c|c|c|c|c|c|}
\hline \multicolumn{6}{|c|}{1 st set of results } \\
\hline & (I) & (II) & (III) & (IV) & $(\mathrm{V})$ \\
\hline & no restriction & $<20$ & $<50$ & $\geq 20$ & $\geq 50$ \\
\hline Post & $-0.009 * * *$ & $-0.071 * * *$ & $-0.081 * * *$ & $-0.081 * * *$ & $-0.076 * * *$ \\
\hline Wage Gap & $0.044 * * *$ & $0.142 * * *$ & $0.120 * * *$ & $0.023 *$ & -0.003 \\
\hline Wage Gap* Post & -0.005 & $-0.056^{* * *}$ & $-0.042 * *$ & 0.016 & $0.040 * *$ \\
\hline Controls & No & No & No & No & No \\
\hline Constant & $0.063 * * *$ & $0.190 * * *$ & $0.263 * * *$ & $0.242 * * *$ & $0.171 * * *$ \\
\hline Observations & 182315 & 36023 & 45183 & 39484 & 29765 \\
\hline R-squared & 0.003 & 0.022 & 0.017 & 0.008 & 0.008 \\
\hline \multicolumn{6}{|c|}{ 2nd set of results } \\
\hline & (I) & (II) & (III) & (IV) & (V) \\
\hline & no restriction & $<20$ & $<50$ & $\geq 20$ & $\geq 50$ \\
\hline Post & 0.004 & -0.012 & -0.022 & $-0.025^{*}$ & -0.015 \\
\hline Wage Gap & $2.018 * * *$ & $3.774 * * *$ & $3.144 * * *$ & $3.647 * * *$ & $1.160 * * *$ \\
\hline Wage Gap* Post & $-0.011 * *$ & $-0.077 * * *$ & $-0.083 * * *$ & -0.01 & $0.032 *$ \\
\hline Controls & Yes & Yes & Yes & Yes & Yes \\
\hline Constant & $0.077 * *$ & $-0.540 * * *$ & $-0.307^{* *}$ & -0.089 & 0.219 \\
\hline Observations & 182253 & 36015 & 45170 & 39471 & 29757 \\
\hline R-squared & 0.216 & 0.258 & 0.292 & 0.276 & 0.195 \\
\hline
\end{tabular}

Source: South African Labour Force Survey from 2000 to 2007.

Notes: Controls are included for age, race, education and agricultural real GDP. Dummy variables are included for seasonality and districtcouncils. Asterisks denote $* * * \mathrm{p}<0.01 ; * * \mathrm{p}<0.05 ; * \mathrm{p}<0.1$.

Overall then, most of the disemployment effects caused by the introduction of minimum wages in the agricultural sector occurred on small farms. Despite employment growth on large farms, they 
did not, however, absorb all workers who lost their jobs on small farms. The result is in an overall decrease in employment in the agricultural sector, as already documented by Bhorat et al. (2014). However, the distinctions between small and large farms have not been highlighted before, and provide a nuanced view of the mechanisms by which minimum wages operate in agriculture.

A number of potential explanations exist for why small and large farms responded differently to the introduction of minimum wages. Firstly, larger farms, overall, pay higher wages than small firms as was shown in Table 2: larger farms had a smaller gap to reach minimum wage levels compared to smaller farms. Furthermore, large firms usually have a more capital-intensive production process; this therefore presents as a viable production choice mainly for larger farms who can exploit economies of scale; therefore costs in larger farms rise by a smaller proportion than in smaller farms when minimum wages are introduced. Both of these factors indicate that minimum wages could place a bigger burden on small farms compared to bigger farms. This burden could drive small farms out of the market, where the disemployment effects do not only suggest that the number of workers employed decreased, but that some small farms had to shut down or merge with larger farms. In the latter case, growth in large farm employment can be explained by a combined workforce. This finding is in line with Rankin (2016) who showed that small firms in a tradable sector (manufacturing), which are exposed to external competition, are more sensitive to increasing wages and often need to exit the market as a result.

The result is that there is an increase in the concentration of employment on larger farms. This raises intra-sectoral inequality of production and intensifies an existing problem. Structural change in the agricultural sector has led to major job destruction over the long-run. In the last three decades alone, agricultural employment has decreased by roughly one million (Liebenberg \& Kirsten, 2013). Moreover, the number of farms decreased, while farm sizes and the number of employees per farm increased. In particular, between 2008 and 2011, the number of farmers in South Africa decreased from 50332 to 34905 (Liebenberg \& Kirsten, 2013; Liebenberg \& Pardey, 2012). Remaining farms increase in size as a result of some farmers exiting agriculture combined with relatively few new entrants in agriculture (Simbi \& Aliber, 2000). Smaller players exited as they could not compete with larger farms who could more easily take advantage of more productive, capital-intensive production processes. Indeed, Garbers (2014) has shown that this overall pattern 
intensified after the imposition of minimum wages: farms have become more capital-intensive and have focused their hiring on better skilled workers. Unskilled jobs were the most affected.

Table 4 below shows whether employers in agriculture responded to the legislation by reducing the number of hours worked. Looking at column 1 in table 4 , one sees that farms reduced the number of hours worked by approximately two hours per week (for every $1 \%$ that the wage gap was narrowed) after minimum wages were introduced relative to the pre-law period. The largest farmers did not adjust hours downwards. Overall, the results suggest that mainly smaller employers adjusted on the intensive margin.

Table 4: Number of hours worked in the agricultural sector

\begin{tabular}{|c|c|c|c|c|c|}
\hline \multicolumn{6}{|c|}{$1 \mathrm{st}$ set of results } \\
\hline & (I) & (II) & (III) & (IV) & (V) \\
\hline & no restriction & $<20$ & $<50$ & $\geq 20$ & $\geq 50$ \\
\hline Post & $-1.46 * * *$ & $-2.45 * * *$ & $-1.70 * * *$ & -0.28 & $-0.99 *$ \\
\hline Wage Gap & $8.15^{* * *}$ & $6.73^{* * *}$ & $8.64 * * *$ & $8.24 * * *$ & $7.26 * * *$ \\
\hline Wage Gap* Post & $-2.23 * * *$ & -0.92 & $-2.03^{* *}$ & $-4.51 * * *$ & -2.75 \\
\hline Individual controls & Yes & Yes & Yes & Yes & Yes \\
\hline Other controls & No & No & No & No & No \\
\hline Constant & $48.62 * * *$ & $50.04 * * *$ & $48.50 * * *$ & $48.49 * * *$ & $48.53 * * *$ \\
\hline Observations & 21948 & 10083 & 16235 & 11441 & 5449 \\
\hline R-squared & 0.039 & 0.032 & 0.042 & 0.039 & 0.037 \\
\hline \multicolumn{6}{|c|}{2 nd set of results } \\
\hline & (I) & (II) & (III) & (IV) & $(\mathrm{V})$ \\
\hline & no restriction & $<20$ & $<50$ & $\geq 20$ & $\geq 50$ \\
\hline Post & $-4.72 * * *$ & $-4.54 * * *$ & $-4.98 * * *$ & $-5.08 * * *$ & $-3.85 * * *$ \\
\hline Wage Gap & 0.67 & -14.27 & -12.00 & $28.50^{*}$ & $25.92 *$ \\
\hline Wage Gap* Post & $-1.86^{* *}$ & -1.14 & $-1.91 * *$ & $-2.93 * *$ & -1.32 \\
\hline Individual controls & Yes & Yes & Yes & Yes & Yes \\
\hline Other controls & Yes & Yes & Yes & Yes & Yes \\
\hline Constant & $50.19 * * *$ & $52.57 * * *$ & $52.22 * * *$ & $47.05^{* * *}$ & $44.45^{* * *}$ \\
\hline Observations & 21948 & 10083 & 16235 & 11441 & 5449 \\
\hline R-squared & 0.06 & 0.07 & 0.07 & 0.07 & 0.08 \\
\hline
\end{tabular}

Source: South African Labour Force Survey from 2000 to 2007.

Notes: Individual controls include age, race and education. Other controls include agricultural real GDP, and dummy variables for seasonality and district-councils. Asterisks denote $* * * \mathrm{p}<0.01 ; * * \mathrm{p}<0.05 ; * \mathrm{p}<0.1$. 
The third outcome variable that is analyzed is the log of real hourly wages. Table 5 presents the results for the agricultural sector and follows the same setup as the table above. The positive and statistically significant coefficient on the interaction term suggests that farmworker wages increased significantly as a result of the introduction of minimum wages. When analysing the results by firm size, one sees that wages grew faster on larger farms than for smaller farms.

These results have clearly shown that wages have increased substantially as a result of the introduction of minimum wages in the agricultural sector and that wages have grown faster on larger farms. This once again points toward the fact that bigger farms appear to be more profitable; they were able to increase wages and employment simultaneously.

Table 5: Log of real hourly wages in the agricultural sector

\begin{tabular}{|c|c|c|c|c|c|}
\hline \multicolumn{6}{|c|}{1 st set of results } \\
\hline & (I) & (II) & (III) & (IV) & $(\mathrm{V})$ \\
\hline & no restrictions & $<20$ & $<50$ & $\geq 20$ & $\geq 50$ \\
\hline Post & $0.17 * * *$ & $0.20 * * *$ & $0.17 * * *$ & $0.11 * * *$ & $0.14 * * *$ \\
\hline Wage Gap & $-0.84 * * *$ & $-0.70 * * *$ & $-0.83 * * *$ & $-0.88 * * *$ & $-0.81 * * *$ \\
\hline Wage Gap* Post & $0.37 * * *$ & $0.31 * * *$ & $0.36^{* * *}$ & $0.51 * * *$ & $0.46^{* * *}$ \\
\hline Individual controls & Yes & Yes & Yes & Yes & Yes \\
\hline Other Controls & No & No & No & No & No \\
\hline Constant & $0.70 * * *$ & $0.60 * * *$ & $0.70 * * *$ & $0.69 * * *$ & $0.69 * * *$ \\
\hline Observations & 21806 & 10036 & 16140 & 11349 & 5405 \\
\hline R-squared & 0.294 & 0.26 & 0.289 & 0.305 & 0.299 \\
\hline \multicolumn{6}{|c|}{2 nd set of results } \\
\hline & (I) & (II) & (III) & (IV) & $(\mathrm{V})$ \\
\hline & no restrictions & $<20$ & $<50$ & $\geq 20$ & $\geq 50$ \\
\hline Post & $0.33 * * *$ & $0.41 * * *$ & $0.34 * * *$ & $0.26^{* * * *}$ & $0.28 * * *$ \\
\hline Wage Gap & -0.44 & -0.68 & -0.21 & $-1.51^{*}$ & -0.90 \\
\hline Wage Gap* Post & $0.34 * * *$ & $0.27 * * *$ & $0.32 * * *$ & $0.41 * * *$ & $0.41^{* * *}$ \\
\hline Individual controls & Yes & Yes & Yes & Yes & Yes \\
\hline Other Controls & Yes & Yes & Yes & Yes & Yes \\
\hline Constant & $0.80 * * *$ & $0.90 * * *$ & $0.78 * * *$ & $0.98 * * *$ & $0.93 * * *$ \\
\hline Observations & 21806 & 10036 & 16140 & 11349 & 5405 \\
\hline R-squared & 0.336 & 0.322 & 0.332 & 0.365 & 0.38 \\
\hline
\end{tabular}

Source: South African Labour Force Survey from 2000 to 2007.

Notes: Individual controls include age, race and education. Other controls include agricultural real GDP, and dummy variables for seasonality and district-councils. Asterisks denote $* * * \mathrm{p}<0.01 ; * * \mathrm{p}<0.05 ; * \mathrm{p}<0.1$. 
In the following section, results for the retail sector are presented. We seek to find out whether small firms in a sector not exposed to international competition also experienced disemployment effects as a result of the introduction of minimum wages.

\subsection{Results for the retail sector}

Within the retail sector, the minimum wage varies according to a number of other legislated classifications. A prominent condition is firm size, which was in place until the end of 2005; firms that employ fewer than 5 workers had a lower legislated minimum wage which was roughly $70 \%$ of the minimum wage payable by firms who employed 5 or more workers. While this concession should reduce differences across firm size categories, descriptive statistics in Table 2 highlighted that the smallest firms nevertheless had larger wage gaps that had to be narrowed in order to comply with minimum wage legislation.

Table 6 shows the impact of the introduction of minimum wages on the probability of employment in the retail sector. Table 6 again includes two sets of results: the first set includes no controls, whereas the second includes a full set of controls. Each set of results is in turn comprised of seven regressions. Since the retail minimum wage differed for different firm sizes, the firm size categories are slightly different to those in the agricultural analysis. Column one considers the sector as a whole; column two and three restrict the analysis to firms that employ fewer than 5 and 5 or more employees. The following firm size restrictions are similar to those in agriculture.

Regardless of specification or firm size restriction, minimum wages have no robust impact on employment in the retail sector. Small firm employment - despite having the largest pre-legislation wage gaps - is therefore immune to the imposition of minimum wages. This stands in stark contrast to the agricultural sector, where small farms experienced large employment losses while large farm jobs grew. We posit that retail's protection from international competition makes small firms less vulnerable to wage pressures. They are able to pass on higher wage costs to local consumers, as they are able to set their own prices. 
Table 6: Probability of employment in the retail sector

\begin{tabular}{|c|c|c|c|c|c|c|c|}
\hline \multicolumn{8}{|c|}{$1 \mathrm{st}$ set of results } \\
\hline & (I) & (II) & (III) & (IV) & $(\mathrm{V})$ & (VI) & (VII) \\
\hline & $\begin{array}{c}\text { no } \\
\text { restriction }\end{array}$ & $<5$ & $>5$ & $5-19$ & $5-49$ & $\geq 20$ & $\geq 50$ \\
\hline Post & $0.006^{* * *}$ & 0.000 & $0.010 * *$ & -0.005 & 0.006 & $0.018 * * *$ & 0.009 \\
\hline Wage Gap & $-0.012 * * *$ & $0.013 * *$ & $-0.061 * * *$ & $-0.068 * * *$ & $-0.086 * * *$ & $-0.080 * * *$ & $-0.080 * * *$ \\
\hline Wage Gap* Post & 0.000 & -0.003 & 0.002 & $0.043^{*}$ & 0.019 & -0.011 & -0.001 \\
\hline Controls & No & No & No & No & No & No & No \\
\hline Constant & $0.044 * * *$ & $0.051 * * *$ & $0.126 * * *$ & $0.165^{* * *}$ & $0.152 * * *$ & $0.104 * * *$ & $0.094 * * *$ \\
\hline Observations & 274983 & 48591 & 78786 & 36337 & 56445 & 37527 & 17228 \\
\hline R-squared & 0.000 & 0.000 & 0.002 & 0.001 & 0.003 & 0.006 & 0.005 \\
\hline \multicolumn{8}{|c|}{2 nd set of results } \\
\hline & (I) & (II) & (III) & (IV) & (V) & (VI) & (VII) \\
\hline & $\begin{array}{c}\text { no } \\
\text { restriction }\end{array}$ & $<5$ & $>5$ & $5-19$ & $5-49$ & $\geq 20$ & $\geq 50$ \\
\hline Post & $0.011 * * *$ & $-0.021 * *$ & 0.000 & -0.028 & -0.010 & 0.012 & 0.000 \\
\hline Wage Gap & $-0.194 * * *$ & -0.032 & $-0.088^{*}$ & -0.248 & $-0.128 *$ & $-0.132 *$ & $-0.197 *$ \\
\hline Wage Gap* Post & -0.004 & -0.008 & -0.016 & 0.019 & -0.001 & -0.011 & -0.002 \\
\hline Controls & Yes & Yes & Yes & Yes & Yes & Yes & Yes \\
\hline Constant & $0.058 * * *$ & $0.214 * * *$ & $0.066^{* * *} *$ & 0.040 & $0.053^{*}$ & $0.093 * * *$ & $0.099 * * *$ \\
\hline Observations & 274832 & 48568 & 78736 & 36326 & 56411 & 37489 & 17212 \\
\hline R-squared & 0.031 & 0.061 & 0.067 & 0.077 & 0.077 & 0.068 & 0.062 \\
\hline
\end{tabular}

Source: South African Labour Force Survey from 2000 to 2007.

Notes: Controls are included for age, race and education. Dummy variables are included for seasonality and district- councils. Asterisks denote $* * * \mathrm{p}<0.01 ; * * \mathrm{p}<0.05 ; * \mathrm{p}<0.1$.

Table 7 shows the results for the number of hours worked in the retail sector and has a similar setup as table 4 which showed the number of hours worked results for the agricultural sector. Again, instead of splitting the analysis into four different firm size categories, this analysis is split into six firm size categories, as explained above. No robust, statistically significant hours adjustments occurred in any segment of the retail sector. 
Table 7: The number of hours worked in the retail sector

\begin{tabular}{|c|c|c|c|c|c|c|c|}
\hline \multicolumn{8}{|c|}{ 1st set of results } \\
\hline & (I) & (II) & (III) & (IV) & $(\mathrm{V})$ & (VI) & (VII) \\
\hline & $\begin{array}{c}\text { no } \\
\text { restriction }\end{array}$ & $<5$ & $>5$ & $5-19$ & $5-49$ & $\geq 20$ & $\geq 50$ \\
\hline Post & -0.58 & -1.83 & -0.37 & -0.84 & -0.51 & -0.25 & 0.42 \\
\hline Wage Gap & $8.14 * * *$ & $4.01 * *$ & $6.30 * * *$ & $3.16^{* *}$ & $6.38 * * *$ & 2.50 & 2.16 \\
\hline Wage Gap* Post & -1.59 & -0.6 & 0.59 & 1.78 & -0.68 & 3.96 & 6.55 \\
\hline Individual controls & Yes & Yes & Yes & Yes & Yes & Yes & Yes \\
\hline Other controls & No & No & No & No & No & No & No \\
\hline Constant & $54.35 * * *$ & $62.91 * * *$ & $50.64 * * *$ & $53.78 * * *$ & $52.07 * * *$ & $46.57 * * *$ & $39.67 * * *$ \\
\hline Observations & 11203 & 2599 & 8111 & 4898 & 6763 & 2983 & 1182 \\
\hline R-squared & 0.065 & 0.101 & 0.046 & 0.044 & 0.047 & 0.044 & 0.055 \\
\hline \multicolumn{8}{|c|}{2 nd set of results } \\
\hline & (I) & (II) & (III) & (IV) & $(\mathrm{V})$ & (VI) & (VII) \\
\hline & $\begin{array}{c}\text { no } \\
\text { restriction }\end{array}$ & $<5$ & $>5$ & $5-19$ & $5-49$ & $\geq 20$ & $\geq 50$ \\
\hline Post & $-2.41 * * *$ & $-5.94 * *$ & -1.06 & -1.62 & $-1.77 *$ & -1.17 & 1.08 \\
\hline Wage Gap & 0.25 & -6.88 & 0.50 & -14.94 & 1.92 & 3.56 & -14.51 \\
\hline Wage Gap* Post & -1.99 & -1.35 & 0.32 & 2.106 & -0.77 & 2.99 & 6.22 \\
\hline Individual controls & Yes & Yes & Yes & Yes & Yes & Yes & Yes \\
\hline Other controls & Yes & Yes & Yes & Yes & Yes & Yes & Yes \\
\hline Constant & $51.67 * * *$ & $63.77 * * *$ & $47.69 * * *$ & $53.03 * * *$ & $49.68 * * *$ & $42.12 * * *$ & $36.85^{* * *}$ \\
\hline Observations & 11203 & 2599 & 8111 & 4898 & 6763 & 2983 & 1182 \\
\hline R-squared & 0.096 & 0.156 & 0.076 & 0.082 & 0.077 & 0.094 & 0.108 \\
\hline
\end{tabular}

Source: South African Labour Force Survey from 2000 to 2007.

Notes: Controls are included for age, race and education. Dummy variables are included for seasonality and district- councils. Asterisks denote $* * * \mathrm{p}<0.01 ; * * \mathrm{p}<0.05 ; * \mathrm{p}<0.1$

Lastly, table 8 shows the impact of the introduction of minimum wages on log real wages in the retail sector. As evident from column one, wages in the retail sector as a whole increased as a result of minimum wages. Results for the different firm size categories are somewhat mixed but all specifications indicate that wages for firms with 5-49 workers increased. In contrast to agriculture, wage increases proceeded without any adjustments in employment. We posit that limited exposure to international trade enabled firms to pass on the higher wage costs on to local customers. 
Table 8: Log of real hourly wages in the retail sector

\begin{tabular}{|c|c|c|c|c|c|c|c|}
\hline \multicolumn{8}{|c|}{1 st set of results } \\
\hline & (I) & (II) & (III) & (IV) & (V) & (VI) & (VII) \\
\hline & $\begin{array}{c}\text { no } \\
\text { restriction }\end{array}$ & $<5$ & $>5$ & $5-19$ & $5-49$ & $\geq 20$ & $\geq 50$ \\
\hline Post & $0.06 * * *$ & 0.07 & $0.05 * *$ & 0.04 & $0.06 * *$ & $0.07 * *$ & 0.02 \\
\hline Wage Gap & $-0.89 * * *$ & $-0.55 * * *$ & $-0.80 * * *$ & $-0.69 * * *$ & $-0.72 * * *$ & $-0.47 * * *$ & $-0.69 * * *$ \\
\hline Wage Gap* Post & $0.23 * * *$ & 0.11 & $0.20 *$ & 0.17 & $0.24 * *$ & 0.03 & 0.18 \\
\hline Individual controls & Yes & Yes & Yes & Yes & Yes & Yes & Yes \\
\hline District controls & No & No & No & No & No & No & No \\
\hline Time dummies & No & No & No & No & No & No & No \\
\hline Constant & $0.23 * * *$ & -0.07 & $0.53 * * *$ & $0.57 * * *$ & $0.56^{* * *}$ & $0.53 * * *$ & $0.57 * * *$ \\
\hline Observations & 11147 & 2592 & 8065 & 4879 & 6725 & 2958 & 1174 \\
\hline R-squared & 0.340 & 0.410 & 0.30 & 0.290 & 0.30 & 0.280 & 0.270 \\
\hline \multicolumn{8}{|c|}{2 nd set of results } \\
\hline & (I) & (II) & (III) & (IV) & (V) & (VI) & (VII) \\
\hline & $\begin{array}{c}\text { no } \\
\text { restriction }\end{array}$ & $<5$ & $>5$ & $5-19$ & $5-49$ & $\geq 20$ & $\geq 50$ \\
\hline Post & $0.27 * * *$ & $0.27 * *$ & $0.22 * * *$ & $0.22 * *$ & $0.23 * * *$ & 0.22 & 0.12 \\
\hline Wage Gap & $-1.12 * *$ & 0.29 & $-0.54 * * *$ & 0.05 & -0.35 & $-1.05 * * *$ & $-2.41 * * *$ \\
\hline Wage Gap* Post & $0.21 * * *$ & $0.15^{*}$ & $0.17 *$ & 0.14 & $0.19 * *$ & 0.08 & $0.35^{*}$ \\
\hline Individual controls & Yes & Yes & Yes & Yes & Yes & Yes & Yes \\
\hline District controls & Yes & Yes & Yes & Yes & Yes & Yes & Yes \\
\hline Time dummies & Yes & Yes & Yes & Yes & Yes & Yes & Yes \\
\hline Constant & $0.38 * * *$ & -0.09 & $0.65 * * *$ & $0.55 * * *$ & $0.63 * * *$ & $0.76^{* * *}$ & $0.70 * * *$ \\
\hline Observations & 11147 & 2592 & 8065 & 4879 & 6725 & 2958 & 1174 \\
\hline R-squared & 0.420 & 0.50 & 0.370 & 0.370 & 0.370 & 0.350 & 0.330 \\
\hline
\end{tabular}

Source: South African Labour Force Survey from 2000 to 2007.

Notes: Controls are included for age, race and education. Dummy variables are included for seasonality and district- councils. Asterisks denote $* * * \mathrm{p}<0.01 ; * * \mathrm{p}<0.05 ; * \mathrm{p}<0.1$.

\section{$\underline{\text { 5. Conclusion }}$}

The relationship between minimum wages and employment outcomes has been debated for many years. Until today, there is no consensus among economists on the nature of this relationship. Substantial heterogeneity exists in the effects of minimum wages. While the South African literature analyses many different sectors, it had not looked at mechanisms underlying the effects measured. Previous results show that, overall, non-tradable sectors experienced no disemployment 
effects; however agriculture, a tradable export sector, experienced large disemployment effects. This paper emphasizes that most of the disemployment effects were concentrated on small farms that do not have the same ability to invest in capital and better skilled workers as larger farms do. Large farms, in contrast, experienced employment growth as a result of the introduction of minimum wages. However, since larger farms employ more skilled workers and have a more capital-intensive production process, the least skilled, who are supposed to benefit from minimum wages, are losing out. Overall, the increasing concentration of farming among larger players over time was intensified by the introduction of agricultural minimum wages. Minimum wages therefore contribute to intra-industry inequality among farmers. These results should largely be read in the historical context of South Africa's agricultural sector, where success is determined by being a large player. These conclusions differ from previous results, in that they take into account intra-industry dynamics; in particular we show the debilitating effect of minimum wages for small farmers who are less adept at competing in international markets than large farmers.

By contrast, these distinctions are not apparent in the retail sector. Small and large firms were equally immune to job loss. What sets this sector apart from agriculture is that retail sales are not sensitive to external pressures. Small and large operators compete locally, enabling all retail firms to increase prices and thereby shifting the burden of increasing labour costs onto consumers.

Our results therefore show that the imposition of a national minimum wage will likely have heterogeneous effects. While it is possible that overall the impact could be negligible, this finding ignores the definite role it could have in reducing small firm employment in tradable sectors. While the National Development Plan targets small firms for job growth (Republic of South Africa, 2013), the national minimum wage makes limited provision for their vulnerability in specific sectors. A uniform approach to minimum wage design could therefore raise intra-industry inequality in tradable sectors, despite potentially having an equalizing cross-economy effect. 


\section{$\underline{\text { 6. Bibliography }}$}

Allegretto, S. A., Dube, A., \& Reich, M. 2011. Do minimum wages really reduce teen employment? Accounting for heterogeneity and selectivity in state panel data. Industrial Relations, 50(2):205-240.

Arango, C.A. \& Pachon, A. 2007. The minimum wage in Columbia 1984-2001: Favoring the middle class with a bite on the poor. Ensayos sobre Politica Economica, 25(55):149-193.

Bell, B.D. 1997. The performance of immigrants in the United Kingdom: Evidence from the GHS. The Economic Journal, 107(441):333-344.

Bhorat, H. 2000. Are minimum wage adjustments an effective mechanism for poverty alleviation? Some simulations for domestic and farm workers. Paper presented at the Trade and International Policy Secretariat (TIPS) 2000 annual forum. Development Policy Research Unit, South Africa.

Bhorat, H., Kanbur, R., \& Mayet, N. 2012. Minimum wage violation in South Africa. International Labor Review, 151(3):277-287.

Bhorat, H., Kanbur, R., \& Mayet, N. 2013. The impact of sectoral minimum wage laws on employment, wages, and hours of work in South Africa. IZA Journal of Labor \& Development, 2(1):1-27.

Bhorat, H., Kanbur, R., \& Stanwix, B. 2014. Estimating the impact of minimum wages on employment, wages and non-wage benefits: The case of Agriculture in South Africa. American Journal of Agricultural Economics.1-18.

Burger, R.P, Jafta, R.C.C., \& von Fintel, D.P. 2016. Affirmative action policies and the evolution of post-apartheid South Africa's racial wage gap, WIDER Working Paper Series 2016/66, World Institute for Development Economic Research.

Bossler, M. \& Gerner, H-D. 2016. Employment effects of the new German minimum wage: Evidence from establishment-level micro data. IAB Discussion Paper 10/2016, Institute for Employment Research, Nuremberg.

Brown, C., Kilroy, C., \& Kohen, A. 1982. The effect of the minimum wage on employment and unemployment. Journal of Economic Literature, 20(2):487-528. 
Card, D. 1992a. Do minimum wages reduce employment? A case study of California, 1987-89. Industrial and Labor Relations Review, 46(1):38-54.

Card, D. 1992b. Using regional variation in wages to measure the effects of the federal minimum wage. Industrial and Labor Relations Review, 46(1):22-37.

Card, C. \& Krueger, A.B. 1994. Minimum wages and employment: A case study of the fast-food industry in New Jersey and Pennsylvania. American Economic Review, 84(4):772-793.

Card, D. \& Krueger, A.B. 1995. Myth and measurement: The new economics of the minimum wage. Princeton, NJ: Princeton University Press.

Card, D. \& Krueger, A.B. 2000. Minimum wages and employment: A case study of the fast-food industry in New Jersey and Pennsylvania: Reply. The American Economic Review, 90(5):13971420.

Cassim, A. \& Jourdan, B., \& Pillay, K. 2015. The misunderstood minimum wage: A case study of South Africa. Chapter in Global Wage Debates: Politics or Economics? [Online]. Available: http://justjobsnetwork.org/wp-content/pubs/reports/Joint\%20Report\%202015.pdf.

$[2015$, December 20].

Conradie, B. 2004. Wages and wage elasticities for table grapes in South Africa. CSSR Working Paper No. 90, Centre for Social Science Research, South Africa.

Del Carpio, X., Nguyen, H. \& Choon Wang, L. 2012. Does the Minimum Wage Affect Employment? Evidence from the Manufacturing Sector in Indonesia. Policy Research working paper No. 6147. World Bank, Washington, DC.

Dinkelman, T. \& Ranchod, V. 2012. Evidence on the impact of minimum wage laws in an informal sector: Domestic workers in South Africa. Journal of Development Economics, 99(1):27-45.

Dube, A., Lester, T. W., \& Reich, M. 2010. Minimum wage effects across state borders: Estimates using contiguous counties. Review of Economics and Statistics, 92(4):945-964.

Edwards, L., Sanfilippo, M. \& Sundaram, A. 2017. Importing and Firm Export Performance: New Evidence from South Africa. South African Journal of Economics, 86(S1):79-95. 
Fajnzylber, P. 2001. Minimum wage effects throughout the wage distribution: Evidence from Brazil's formal and informal sectors. Proceedings of the $29^{\text {th }}$ Brazilian Economics Meeting 098, Brazilian Association of Graduate Programs in Economics.

Fedderke, J., Kularatne, C. \& Mariotti, M. 2006. Mark-up Pricing in South African Industry. Journal of African Economies, 16(1):28-69.

Garbers, C. 2014. The impact of the agricultural minimum wage on farmworker employment in South Africa: A fixed effects approach. Unpublished master's dissertation. Stellenbosch, University of Stellenbosch.

Gindling, T.H. \& Terrell, K. 2005. The effect of minimum wages on actual wages in formal and informal sectors in Costa Rica. World Development, 33(11):1905-1921.

Gindling, T.H. \& Terrell, K. 2007. The effects of multiple minimum wages throughout the labour market: The case of Costa Rica. Labour Economics, 14(3):485-511.

Hertz, T. 2005. The effect of minimum wages on the employment and earnings of South Africa's domestic service workers. Upjohn Institute Working Paper No. 05-120.

Katz, L.F. \& Krueger, A.B. 1992. The effect of the minimum wage on the fast food industry. Industrial and Labor Relations Review, 46(1):6-21.

Kerr, A., Wittenberg, M. \& Arrow, J. 2014. Job Creation and Destruction in South Africa. South African Journal of Economics, 82 (1): 1-18.

Lee, D. 1999. Wage Inequality in the United States During the 1980s: Rising Dispersion or Falling Minimum Wage? Quarterly Journal of Economics, 114:977-1023.

Leibbrandt, M., Woolard, C. \& Woolard, I., 2009. Poverty and Inequality Dynamics in South Africa: Post-Apartheid Developments in the Light of the Long-Run Legacy. In J. Aron, B. Kahn \& G. Kingdon, eds. South African Economic Policy under Democracy. Oxford. Oxford University Press.

Liebenberg, F. \& Kirsten, J. 2013. Statistics on farm labour in South Africa. [Online]. Available: http://www.up.ac.za/media/shared/Legacy/sitefiles/file/48/2052/2013workingpaperseries/statistic sonfarmlabourup17okt228nov13.pdf. [2016, January 13]. 
Liebenberg, F. \& Pardey, P., 2012. A long-run view of South African agricultural production and productivity. African Journal of Agricultural and Resource Economics, 7(1):14-38

Lustig, N., Lopez-Calva, L.F. \& Ortiz-Juarez, E. 2013. Declining Inequality in Latin America in the 2000s: The Cases of Argentina, Brazil, and Mexico. World Development, 44: 129-141.

Machin, S. \& Manning, A. 1994. Minimum wages, wage dispersion and employment: Evidence from the UK wages councils. Industrial and Labor Relations Review, 47(2):319-329.

Magruder, J.R. 2012. High unemployment yet few small firms: The role of centralized bargaining in South Africa. American Economic Journal: Applied Economics, 4(3):138-166.

Maloney, W. \& Mendez, J. 2004. Measuring the impact of minimum wages: Evidence from Latin America. In Law and Employment: Lessons from Latin America and the Caribbean, NBER Chapters: 109-130. National Bureau of Economic Research Inc.

Matthee, M., Farole, T., Naughtin, T. \& Rankin, N. 2015. South African Exporters and the Global Crisis: Intensive Margin Shock, Extensive Margin Hangover. South African Journal of Economics, 84(20): 183-198.

Meer, J. \& West, J. 2015. Effects of the minimum wage on employment dynamics. Journal of Human Resources, 39(2):425-450.

Murray, J. \& Van Walbeek, C. 2007. Impact of the sectoral determination for farmworkers in the South African sugar industry: case study of the Kwazulu-Natal north and south coasts. CSSR Working Paper No. 181, Centre for Social Science Research, South Africa.

Neumark, D., Salas, J. M. I., \& Wascher, W. 2014. Revisiting the minimum wage-employment debate: Throwing out the baby with the bathwater? Industrial and Labor Relations Review, 67(3):608-648.

Neumark, D. \& Wascher, W.L. 2000. The effect of New Jersey's minimum wage increase on fastfood employment: A revision using payroll records. American Economic Review, 90(5):13621396.

Neumark, D. \& Wascher, W.L. 2007. Minimum wages and employment. Foundations and Trends in Microeconomics, 3(1-2):1-182. 
Parrot, J. 2004. State minimum wages and employment in small businesses. [Online] Available: http://www.fiscalpolicy.org/minimumwageandsmallbusiness.pdf [2015, December 21].

Rama, M. 2001. The Consequences of Doubling the Minimum Wage: The Case of Indonesia. Industrial and Labor Relations Review, 54(4): 864-881.

Rankin, N., 2016. Labour productivity, factor intensity and labour costs in South African manufacturing. REDI3x3 Working Paper, Cape Town, Research Project on Employment, Income Distribution and Inclusive Growth.

Republic of South Africa, 2013. National Development Plan 2030. [Online] Available: http://www.gov.za/sites/www.gov.za/files/Executive\%20Summary-NDP\%202030\%20$\% 20$ Our\%20future\%20-\%20make\%20it\%20work.pdf [2017, April 19].

Sabia, J. 2006. The effect of minimum wage increases on retail and small business employment [Online]. Available: https://www.epionline.org/wp-content/studies/sabia_05-2006.pdf [2015, December 21].

Simbi, T. \& Aliber, M. 2000. Agricultural employment crisis in South Africa. [Online]. Available: http://www.tips.org.za/files/415.pdf. [2016, January 13].

Sorkin, I. 2015. Are there long-run effects of the minimum wage? Review of Economic Dynamics, 18(2): 306-333.

Vermaak, C., 2012. Tracking poverty with coarse data: evidence from South Africa. Journal of Economic Inequality, 10(2): 239-265. 